\title{
THE EFFECT OF ELECTRONIC WORD OF MOUTH ON ONLINE TRUST AND PURCHASE INTENTION AMONG MILLENNIALS GENERATION ON INSTAGRAM
}

\author{
Hirzianto Shidqi ${ }^{*}$, Yuliati Lilik Noor, Kirbrandoko \\ School of Business, Bogor Agricultural University, Indonesia \\ *E-mail: shirzianto@gmail.com
}

\begin{abstract}
The purpose of this research were (1) to analyze the effect of E-WOM to online trust on Instagram; (2) to analyze the effect of E-WOM to purchase intention on Instagram; (3) to analyze the effect of online trust to purchase intention on Instagram. The quantitative approach is carried out by online survey methods to respondents. The data was collected from July to September 2018. The respondents were determined by purposive sampling technique. Respondents of this research were 20-35 aged people (millennials) who bought fashion products through Instagram in the past months. Data processing technique used in this research were descriptive analysis and SEM (Structural Equation Modeling). The result of this study shows electronic word of mouth was significantly positive to online trust and purchase intention.
\end{abstract}

\section{KEY WORDS}

Electronic word of mouth, online trust, purchase intention, public service.

The use of the internet has developed so rapidly since it first appeared and always increases every year. Based on data from Asosiasi Pengguna Jasa Internet Indonesia (APJII) in 2017 there was 143.26 million people used the internet in Indonesia. The biggest increase occurred in 2013 and 2015 with a percentage of $30.16 \%$ and $24.94 \%$. The increase of internet users could be an opportunity for business people to sell online and maximize their sales by using the internet.

The composition of internet users currently consists of various ages. The biggest composition of internet users was dominated by the age of level 19-34 years which is equal to $49.52 \%$. The majority age range of internet users in Indonesia was millennials generation. Millennials were born in the digital era so they tend to socialize with internet technology that can be accessed anytime and don't need to be meet for interact. Millennials cannot be separated from lifestyle in using social media. The Indonesian internet service providers association noted that as much as $87.13 \%$ of people used social media. The frequently used social media in Indonesia were Instagram 82.6\%, Facebook 66.5\%, and Path $49.6 \%$ (APJII 2017). Based on these data, Instagram is social media most commonly used by generation millennial.

In general, Instagram is a platform for sharing photos by fellow users. However, in the past few years, many people have opened virtual stores on Instagram. The popularity of online shopping has recently led to a new e-commerce paradigm called social commerce (scommerce). S-commerce is considered part of e-commerce which known by using social media to facilitate the interaction and communication between consumers and sellers about any products or services (Che et al. 2017). Supported by Jakpat survey data (2017), online sellers in Indonesia who using the Instagram platform were recorded as much as $26.02 \%$ in 2015 and increased to $60 \%$ in 2017 . This thing triggered competition among business people on Instagram. As time passes, Instagram was used as a platform for new businesses to offer products. Based on the results of the Jakpat survey (2016) product which sold on Instagram are fashion (67.5\%), accessories (64.9\%), electronics (35.1\%), cosmetics (32.5\%), culinary $(31.6 \%)$, toys $(14.9 \%)$, and others $(4.4 \%)$. Fashion product is the biggest product category which sold on Instagram.

Trust in online shopping was the important issue for consumer purchasing dicisions in Instagram. Consumer trust is the main key for online buying decisions (Lu et al. 2016). 
One of the way to increase trust is through the exchange of information between Instagram users by electronic word-of-mouth (E-WOM), where consumers share their personal opinions with others about brand, product and service reviews. E-WOM has a high impact on consumer decision making processes (Park \& Kim 2008). Based on the Jakpat survey data (2017) Instagram users who active in buying online are only $12 \%$, this number is the smallest number compared to other activities such as activity give like (63\%), post photo (57\%), read timeline (55\%), watch videos (52\%), and give comments (47\%).

\section{LITERATURE REVIEW}

Electronic Word of Mouth (E-WOM). E-WOM communication can be done in various ways such as posting opinions, comments, and product reviews on weblogs, discussion forums, websites, e-bulletin board systems, newsgroups, social networking sites (Cheung \& Thadani 2010). According to Goyette et al. (2010) E-WOM were divided into three dimensions, namely intensity, valence of opinion, and content. Intensity is the number of opinions written by consumers on a social networking site. Valence of opinion is the opinion of consumers whether positive or negative about products, services and brands. Content is the content of information from social networking sites related to products and services.

Online trust. Trust is very important in many transactional relationships that contain elements of risk, such as transaction with sellers on the internet (Reichheld \& Schefter 2000). McKnight (2002) divided into three dimensions of trust based on confidence in a seller, namely benevolence, integrity and competence. Benevolence is the extent to which a business partner focuses on the welfare of consumers and for mutual benefit. Integrity is a person's belief that the company makes an agreement in good faith about the quality of products and services provided to its customers. Competence is the seller's ability to do what consumers need.

Purchase intention. According to Pavlou (2003), purchase intention is a situation where consumers are able and intend to be involved in online transactions. Purchase intention according to Assael (1998) is a behavior that appears as a response to an object or its also an interest in repurchasing which shows the customer's desire to make a repeat purchase.

Previous research for the effect of E-WOM on online trust has been carried out. The results of Awad \& Ragowksy's study (2008) show that E-WOM has a significant effect on online trust. In addition, the research results of Durmaz \& Yukzel (2017) show that E-WOM has a significant effect on purchase intention. The objects of this research were e-commerce users. The results of the study by Kooli et al. (2014) show that online trust has a positive and significant effect on purchase intention. The objects of this research were users of kaskus.co.id.

\section{METHODS OF RESEARCH}

This research used cross sectional method with the quantitative approach was carried out by online survey methods to respondents. The data was collected from July to September 2018. The respondents were determined by purposive sampling technique. Respondents of this research were 20-35 aged people who bought fashion products through Instagram in the past months. This research used 196 respondents as sample. Data processing technique used in this research were SEM (Structural Equation Modeling) with AMOS 22 software and descriptive analysis with SPSS 22.

\section{CONCEPTUAL FRAMEWORK}

Based on the empirical studies conducted, it was assumed that electronic word of mouth has an effect to online trust and purchase intention. The conceptual framework was presented in Figure 1.

Based on the conceptual framework above, the proposed research hypotheses are:

$\mathrm{H} 1$ : Electronic word of mouth has a positive and significant effect on online trust; 

intention;

H2: Electronic word of mouth has a positive and significant effect on purchase

H3: Online trust has a positive and significant effect on purchase intention.

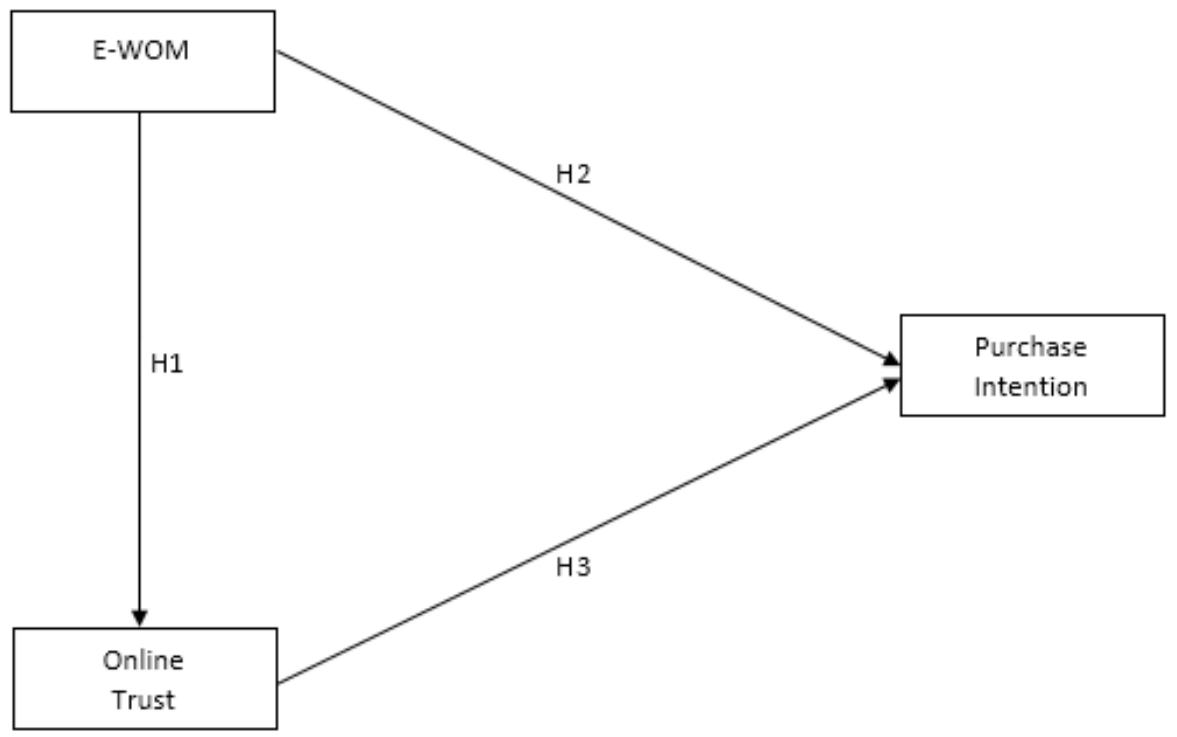

Figure 1 - Conceptual Research Framework

\section{RESULTS AND DISCUSSION}

Respondent Characteristics. Based on the results of the study, the characteristics of respondents were in the age range of 20-25 years. The majority of respondents are women. The domicile of most shopping through Instagram is West Java. Respondents who have jobs as private employees dominate shopping activities through Instagram by spending $\geq \mathrm{Rp}$. 3,000.001 per month with the last education as bachelor's degree.

Overall Model Fit. The effect of electronic word of mouth on online trust and purchase intention on Instagram was measured by using SEM analysis. Model suitability test can be seen from the criteria of GFI, RMSEA, AGFI, CFI, and RMR completely can be seen in Table 1. The overall value of the aspects of the conformity criteria has included the category of Good Fit and Marginal Fit so that the overall research model is feasible.

Table 1 - Overall model fit

\begin{tabular}{llll}
\hline Goodness of Fit & Cut off value & Result & Conclusion \\
\hline Good Fit Index (GFI) & $0.80 \leq$ GFI $<0.90$ or $\geq 0.90$ & 0.903 & Good fit \\
Root Mean Square Error Approximation (RMSEA) & RMSEA $\leq 0.08$ & 0.046 & Close fit \\
Adjusted Good Fit Index (AGFI) & $0.80 \leq A G F I<0.90$ or $\geq 0.90$ & 0.872 & Marginal fit \\
Comparative Fit Index (CFI) & $0.80 \leq C F I<0.90$ or $\geq 0.90$ & 0.971 & Good fit \\
Tucker Lewis Index (TLI) & $0.80 \leq T L I<0.90$ or $\geq 0.90$ & 0.966 & Good fit \\
\hline
\end{tabular}

Table 1 shows the goodness-of fit statistics that the structural model was reasonably well. The model produced a chi-square of 224.149 (df $=159, p=0.001)$. To alleviate the sensitivity of the chi-square statistics, the value of chi-square was divided by the degrees of freedom. The re-estimated chi-square value was 1.41 and this new value is within an acceptable cut-off value range, from 1.0 to 3.0. The goodness of fit is index (GFI =0.903, with 1 indicating maximum fit), root mean square error of approximation (RMSEA $=0.046$, with values $\leq 0.08$ is good fit while $\leq 0.05$ is close fit) adjusted good fit index (AGFI $=0.872,1=$ maximum fit), comparative fit index ( $\mathrm{CFI}=0.971$, with 1 indicating maximum fit), and tucker lewis index $(\mathrm{TLI})=0.966$, with 1 indicating maximum fit). The overall value of the aspects of 
the conformity criteria has been included in the category of Good Fit and Marginal Fit so that overall the research model is feasible.

Measurement Model. Table 2 illustrated factor loadings and Cronbach's alpha coefficients of research variables. As shown, all of the alphas are higher than 0.6 and factors loadings are more than acceptable level of 0.5 , it can be concluded that the indicators used in this study have good or capable reliability to measure the construct and good convergent validity of the questionnaire.

Table 2 - Measurement SEM model

\begin{tabular}{|c|c|c|c|}
\hline Variable & Indicator & Factor Loading & CR \\
\hline \multirow{8}{*}{ Electronic Word of Mouth } & Frequency of accessing information from Instagram (IN1) & 0.64 & \multirow{8}{*}{0.93} \\
\hline & Frequency of interaction with Instagram users (IN2) & 0.68 & \\
\hline & Number of reviews written by Instagram users (IN3) & 0.76 & \\
\hline & Positive comments from Instagram users (VO1) & 0.89 & \\
\hline & Recommendations from Instagram users (VO2) & 0.87 & \\
\hline & Product variation information from Instagram users (CO1) & 0.87 & \\
\hline & Product quality information from Instagram users (CO2) & 0.74 & \\
\hline & Information about prices offered by Instagram users (CO3) & 0.80 & \\
\hline \multirow{9}{*}{ Online Trust } & Make transactions honestly (INT1) & 0.82 & \multirow{9}{*}{0.94} \\
\hline & Tell what really is (INT2) & 0.83 & \\
\hline & Maintaining commitment (INT3) & 0.81 & \\
\hline & Make sure to give the best to customers (BEN1) & 0.81 & \\
\hline & Will provide assistance if needed (BEN2) & 0.75 & \\
\hline & Caring for customer welfare not just a personal benefit (BEN3) & 0.80 & \\
\hline & Able to do properly transactions (COM1) & 0.81 & \\
\hline & Having adequate resources (COM2) & 0.76 & \\
\hline & Having sufficient knowledge in running a business (COM3) & 0.73 & \\
\hline \multirow{3}{*}{ Purchase Intention } & Possibility to buy products from the seller (MB1) & 0.86 & \multirow{3}{*}{0.84} \\
\hline & Will consider buying products from the seller (MB2) & 0.65 & \\
\hline & Intending to buy products from the seller (MB3) & 0.87 & \\
\hline
\end{tabular}

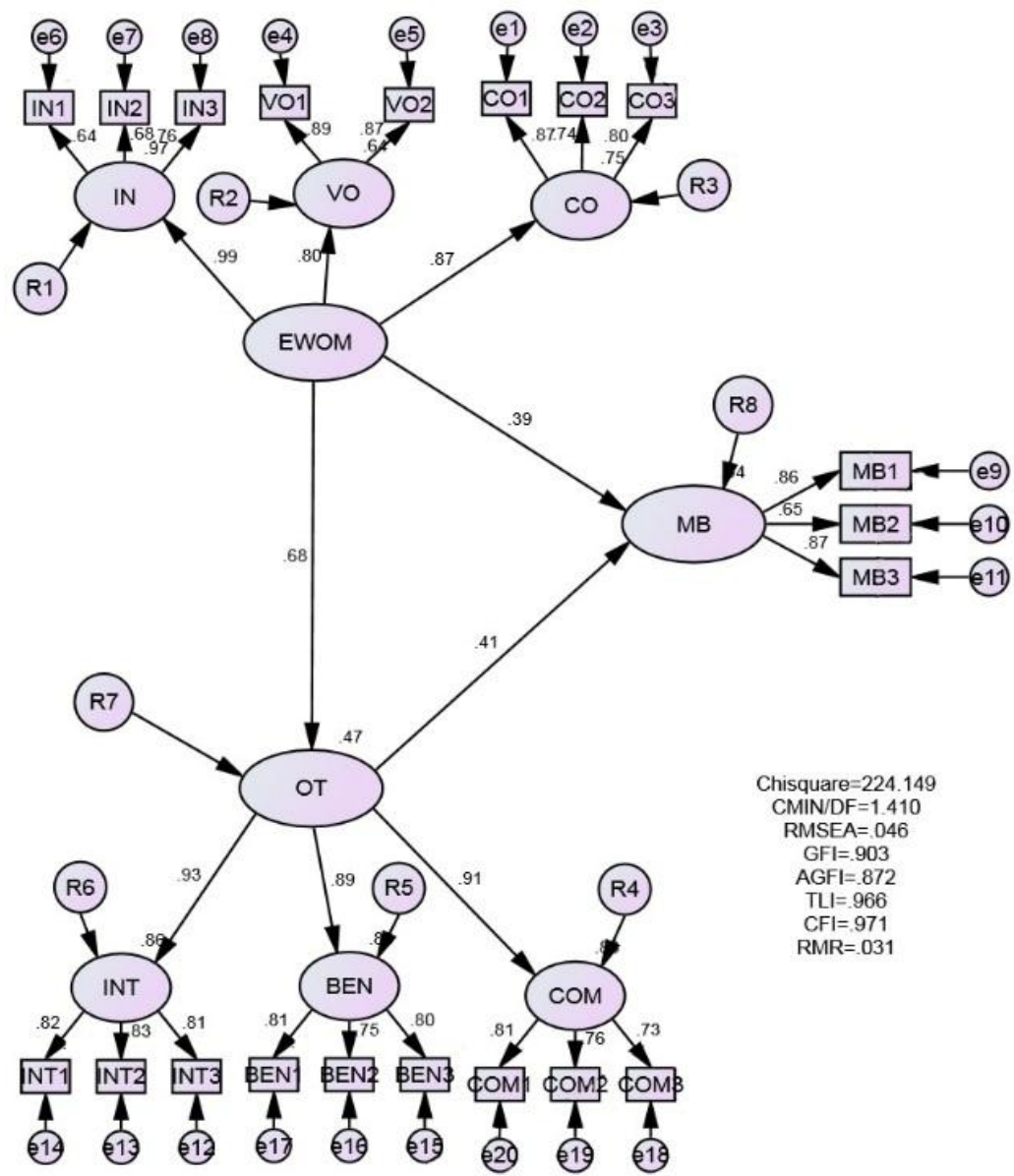

Figure 2 - SEM model on fashion products 
Structural Model Fit. The next step is to test the compatibility of the structural model fit. The compatibility test of structural equation coefficients by specifying a significant level. In this study the significance test used a significance level of 0.05 with a confidence level of $95 \%$. At the 0.05 significance level the $t$ value of each coefficient of the structural equation must be greater than 1.96. Based on Figure 2, it can be seen that the hypotheses one, two, and three are acceptable and significant because the value of $t$ is greater than 1.96 and $p$ value is under 0.05 . Based on the empirical model proposed in this study, testing of hypotheses can be done through testing path coefficients in structural equation models. The following results of the SEM model estimation can be seen in Table 2.

Table 2 - Estimated result of SEM Model

\begin{tabular}{llllllll}
\hline Variable effect & & & Path coefficient & T-Value & P-Value & Conclusion & Information \\
\hline Electronic word of mouth & $\rightarrow$ & Online trust & 0.68 & 7.58 & 0.000 & Significant & Accept \\
Electronic word of mouth & $\rightarrow$ & Purchase intention & 0.39 & 3.85 & 0.000 & Significant & Accept \\
Online trust & $\rightarrow$ & Purchase intention & 0.41 & 4.06 & 0.000 & Significant & Accept \\
\hline
\end{tabular}

Based on SEM model, electronic word of mouth had a positive and significant impact on online trust (path coefficient $=0.68, t=7.58$ ). Electronic word of mouth also had a positive effect on purchase intention (path coefficient $=0.39, t=3.85$ ). Finally, online trust had a positive effect on purchase intention in the context of fashion product (path coefficient $=0.41$, $\mathrm{t}=4.06$ ).

Effect electronic word of mouth on online trust. The results of the study found that the first hypothesis was accepted, electronic word of mouth had a positive and significant effect on online trust. This analysis is also supported by Awad \& Ragowksy's (2008) study, Prasad et al. (2017). Based on the findings, respondents felt that positive comments from Instagram users were the most important indicator in electronic word of mouth. Electronic word of mouth is an important tool for information gain about service or product (Chevalier \& Mayzlin 2006). Consumers feel that the source of information Electronic word of mouth is the perception of other consumers and not sponsored by a company (Goyette et al. 2010). So that makes consumers are trust to the seller.

Effect electronic word of mouth on purchase intention. The results of the study found that the second hypothesis was accepted, electronic word of mouth has a positive and significant effect on purchase intention. This analysis is also supported by previous research conducted by Durmaz \& Yukzel (2017), Kudeshia \& Kumar (2017). Based on the findings, respondents felt that positive comments from Instagram users were the most important indicator in electronic word of mouth. Chatterjee (2001) state that this kind of message can effectively reduce risk and uncertainty which recognized by consumers when purchasing products or services, so that their purchase intention can be further influenced. Product reviews posted by consumers on the internet are one of the most important ways of EWOM communication (Sen \& Lerman 2007).

Effect online trust on purchase intention. The results of the study found that the third hypothesis was accepted, online trust has a positive and significant effect on purchase intention. This analysis is also supported by previous research conducted by Che et al. (2017), Kooli et al. (2014). Based on the findings, respondents felt if seller tell what really is were the most important indicator in online trust. Consumers may feel uncomfortable because cannot physically check the quality of the products while shopping on the internet (Ling et al. 2010). When the seller can tell the actual condition or specification it will reduce suspicion and uncertainty which will increase consumer buying interest.

\section{MANAGERIAL IMPLICATIONS}

Based on the results of the study, electronic word of mouth is the most influential variable on online trust. The intensity dimension has the greatest value in forming electronic word of mouth, sellers must pay more attention to information, interactions and the number of opinions written by consumers on Instagram. The seller can take advantage of the highlight 
feature on Instagram, for example the seller collects opinions written by consumers, so that consumers are more confident and stimulated to make purchases. In addition to increasing the number of opinions written by consumers, sellers can carry out promotional strategies to give discounts to consumers who are willing to take photos or review products purchased.

Online trust plays an important role in purchase intention. Dimensions of integrity have the greatest value in forming online trusts. Consumer trust to the seller must be built, Instagram is not like e-commerce that has a transaction feature, the seller must be able to make transactions honestly. The seller can display a receipt picture post from previous transactions so that prospective customers feel more confident. In addition, the method that can be done by the seller is to provide information about the product in the caption column, such as whether the product is original or not, the material and the quality of the product. The seller can use a photo of the original product with a detailed watermark or the name of the seller in the photo. In addition, sellers can include videos of these products by utilizing Instagram features, which in one post can upload multiple files to reduce the uncertainty felt by consumers.

\section{CONCLUSION}

Electronic word of mouth has a positive impact on online trust. This positive effect shows that trust in sellers on Instagram can be increased through interactions, comments, posts and reviews of Instagram users. Electronic word of mouth also has a positive impact on purchase intention. This positive effect indicates that purchase intention on Instagram can be increased through Electronic word of mouth. Online trust has a positive effect on purchase intention. The positive effect shows that purchase intention on Instagram can be increased through trust that has been firmly instilled on sellers in Instagram.

\section{RECOMMENDATIONS}

Based on the research findings, purchase intention can be improved through electronic word of mouth and online trust. Sellers on Instagram can implement the managerial implications of this research. Sellers Instagram needs to develop things that have been achieved so far such as promotion strategy through electronic word of mouth to increase online trust so that it will be increase purchase intention. For further research, it is recommended to do research on another product category such as accessories, electronics, culinary, or toys. Furthermore, it is also advisable to add and use other variables that affect purchase intention, such as perceived risk, electronic service quality, and marketing mix and so forth to get more comprehensive research findings.

\section{REFERENCES}

1. APJII. 2017. Survei Asosiasi Penyelenggara Jasa Internet Indonesia. Diakses 11 April 2018. www.apjii.or.id.

2. Assael H. 1998. Customer Behaviour and Marketing Actions 2nd. New York (US): International Thomson Publishing.

3. Awad NF, Ragowsky A. 2008. Establishing trust in electronic commerce through online word of mouth: An examination across genders. Journal of Management Information Systems. 24(4). 101-121.

4. Chatterjee P. 2001. Online Reviews: Do Consumers Use Them?. Advances in Consumer Research Proceedings. 28. 129-134.

5. Che JWS, Cheung MK, Thadani DR. 2017. Consumer Purchase Decision in Instagram Stores: The Role of Consumer Trust. Proceedings of the 50th Hawaii International Conference on System Sciences. 24-33.

6. Cheung MK, Thadani DR. 2010. The Effectiveness of Electronic Word-of-Mouth Communication: A Literature Analysis. BLED Proceedings. 18. 329-345. 
7. Chevalier JA, Mayzlin D. 2010. The effect of word of mouth on sales: online book consumer reviews on the web. Journal of Interactive Marketing. 21(4). 76-94

8. Durmaz A, Yukzel. 2017. The Effect of E-WOM on purchase intention: Evidence from Ecommerce sites. The Journal of Faculty of Economics and Administrative Sciences. 22(1). 231-239.

9. Goyette I, Ricard L, Bergeron J, Marticotte F .2010. E-Wom: Word of Mouth Measurement Scale for E-Service Context. Canadian Journal of Administrative Sciences. 27(1). 5-23.

10. Jakpat. 2017. Survei Jajakpendapat Indonesian Online Seller. Diakses 11 April 2018. www.jajakpendapat.net.

11. Kooli K, Mansour BK, Utama R. 2014. Determinants of online trust and their impact on online purchase intention. International Journal Technology Marketing. 9(3). 305-317.

12. Kudeshia C, Kumar A. 2017. Social eWOM: Does it affect the brand attitude and purchase intention of brands?. Management Research Review. 40(3). 1-38.

13. Ling KC, Chai LT, Tan HP. 2010. The Effects of Shopping Orientations, Online Trust, Prior Online Purchase Experience toward Customers Online Purchase Intention. International Business Research. 3(3). 63-75.

14. Lu B, Fan W, Zhou M. 2016. Social presence, trust, and social commerce purchase intention: An empirical research. Computers in Human Behavior. 56. 225-237.

15. McKnight DH, Choudhury V, Kacmar C. 2002. Developing and validating trust measures for e-commerce an integrative typology. Information System Research. 13(3). 334-359.

16. Park DH, Kim S. 2008. The effects of consumer knowledge on message processing of electronic word-of-mouth via online consumer reviews. Electronic Commerce Research and Applications. 7(4). 399-410.

17. Pavlou PA. 2003. Consumer Acceptance of Electronic Commerce: Integrating Trust and Risk with the Technology Acceptance Model. International Journal of Electronic Commerce. 7(3). 101-134.

18. Prasad S, Gupta IC \& Totala NK. 2017. Social Media Usage, Electronic Word of Mouth and Purchase Decision Involvement. Asia-Pacific Journal of Business Administration. 9(2). 1-29.

19. Reichheld FF, Schefter P. 2000. E-Loyalty: Your Secret Weapon on the Web. Harvard Business Review. 78(4). 105-113.

20. Sen S, Lerman D. 2007. Why are you telling me this? An examination into negative review. Journal of Marketing Research. 43 (3). 345-54. 